\title{
Playful educational intervention with schoolchildren on intestinal parasitosis
}

\author{
Intervenção educativa lúdica sobre parasitoses intestinais com escolares \\ Intervención educativa lúdica sobre parasitosis intestinales con escolares
}

Gabriela Rodrigues Bragagnollo' ORCID: 0000-0003-1480-8046

Tâmyssa Simões dos Santos" ORCID: 0000-0002-7911-0389

Renata Elizabete Pagotti da Fonseca' ORCID: 0000-0001-9186-7352

Marcelo Acrani' ORCID: 0000-0001-7303-4373

Maria Zita Pires Castelo Branco"' ORCID: 0000-0003-3253-4739

Beatriz Rossetti Ferreira' ORCID: 0000-0002-6781-2236

'Universidade de São Paulo, Escola de Enfermagem de Ribeirão Preto. Ribeirão Preto, São Paulo, Brazil.

"Centro Universitário Mauricio de Nassau. Recife, Pernambuco, Brazil.

I" Universidade de Trás-os-Montes e Alto Douro, Escola Superior de Enfermagem de Vila Rea. Portugal.

How to cite this article: Bragagnollo GR, Santos TS, Fonseca REP, Acrani M, Castelo Branco MZP, Ferreira BR. Playful educational intervention with schoolchildren on intestinal parasitosis. Rev Bras Enferm. 2019;72(5):1203-10. doi: http://dx.doi.org/10.1590/0034-7167-2017-0551

\section{Corresponding Author:}

Gabriela Rodrigues Bragagnollo

E-mail: gabriela.rodrigues.bragagnollo@usp.b

Submission: 08-01-2017 Approval: 04-28-2018

\section{ABSTRACT}

Objective: To analyze the playful educational interventions in the knowledge of schoolchildren about intestinal parasitosis. Method: This is a quasi-experimental, non-randomized study, based on pre- and post-intervention, conducted in a public elementary school in a peripheric neighborhood in the city of Ribeirão Preto (SP). The study population consisted of 101 students enrolled in the 5th and 6th grade. For comparison, we used the generalized version of the McNemar chi-squared test. Results: Of the 101 schoolchildren who participated in the study, 48 (47.5\%) were female and 53 (52.5\%) were male, aged from 9 to 14 years. Students' knowledge on intestinal parasitic infections has increased significantly after the playful educational intervention. Conclusion: Playful educational interventions are an excellent didactical resource in the teaching-learning process of schoolchildren.

Descriptors: Health Education; Parasitic Diseases; Public Health; Teaching Materials; Epidemiology.

\section{RESUMO}

Objetivo: Analisar as intervenções educativas lúdicas no conhecimento de escolares sobre enteroparasitoses. Método: Trata-se de estudo quase-experimental, não randomizado, baseado na pré e pós-intervenção, ocorrido em escola pública de ensino fundamental de um bairro da periferia na cidade de Ribeirão Preto (SP). A população do estudo foi composta por 101 alunos que cursavam o $5^{\circ}$ e $06^{\circ}$ ano. Para efetuar a comparação foi utilizada a versão generalizada do teste qui-quadrado de McNemar. Resultados: Dos 101 escolares que participaram do estudo, 48 (47,5\%) eram do sexo feminino e 53 (52,5\%) do sexo masculino, com idade entre 9 a 14 anos. $O$ conhecimento dos alunos sobre enteroparasitoses após a intervenção educativa lúdica aumentou significativamente. Conclusão: As intervenções educativas lúdicas são um excelente recurso didático no contexto do processo ensinoaprendizagem de escolares.

Descritores: Educação em Saúde; Doenças Parasitárias; Saúde Pública; Materiais de Ensino; Epidemiologia.

\section{RESUMEN}

Objetivo: Analizar las intervenciones educativas lúdicas en el conocimiento de escolares sobre enteroparasitosis. Método: Se trata de estudio casi-experimental, no aleatorizado, basado en la pre y pos-intervención, que ha sido ocurrido en escuela pública de enseñanza primaria de un barrio de la periferia en la ciudad de Ribeirão Preto (SP). La población del estudio ha sido conformada por 101 alumnos que cursaban el $5^{\circ}$ y el $6^{\circ}$ año. Para realizar la comparación ha sido utilizada la versión generalizada de la prueba chi-cuadrada de McNemar. Resultados: De los 101 escolares que han participado del estudio, 48 (el 47,5\%) eran del sexo femenino y 53 (el 52,5\%) del sexo masculino, con edad entre 9 a 14 años. El conocimiento de los alumnos sobre enteroparasitosis después de la intervención educativa lúdica se ha incrementado significativamente. Conclusión: Las intervenciones educativas lúdicas son un excelente recurso didáctico en el contexto del proceso enseñanzaaprendizaje de escolares.

Descriptores: Educación en Salud; Enfermedades Parasitarias; Salud Pública; Materiales de Enseñanza; Epidemiología. 


\section{INTRODUCTION}

Enteropathogenic diseases are a result of the epidemiological triad - agent, host, and environment -, being mainly transmitted via oral-fecal routes. Pointed out by the Ministry of Health (MS) as a serious public health problem, they are closely related to individuals' pauperization. Thus, the high number of people infected with parasitic intestinal diseases is regarded as a bad indicator for the Human Development Index (HDI) of the country ${ }^{(1)}$.

Furthermore, States that are considered to be poorer tend to have a higher prevalence, mainly regarding insalubrious communities, which do not have sanitation and treated water - a fact observed on peripheries of several Brazilian cities ${ }^{(1-2)}$. The National Sanitation Information System (SNIS) has notified that $50.26 \%$ of the Brazilian population suffers from lack of access to sewage collection, representing about 102 million people; only $42.67 \%$ of the population have access to treated sewage in the country. Ribeirão Preto (SP) is ranked as the 22 nd city in the Sanitation Ranking of the 100 Largest Cities ${ }^{(3)}$.

In this scenario, the global epidemiological data indicates that about $50 \%$ of the population is infected by some intestinal parasite, and Africa, Asia, and Latin America are the locations with the highest prevalence ${ }^{(4-5)}$. In Latin America, research has shown that the infection average ranges from $30 \%$ to $53 \%$, and is estimated that about 46 million children/adolescents in school age (from 1 to 14 years old) are under risk of helminth infection ${ }^{(5-7)}$.

In Brazil, it is believed that the prevalence in schoolchildren may reach 70\%; however, in low HDI municipalities, this percentage can range from $2 \%$ to $36 \%$. In the North and Northeast regions of the country, studies indicate a high number of cases of infected schoolchildren ${ }^{(5,8)}$. Regarding the State of São Paulo, there is research on the decreased prevalence of parasitic diseases; however, a significant number of these infections is still evidenced in children ${ }^{(9)}$.

Similarly to the Brazilian reality, Latin American studies conducted in Argentina, Colombia, Venezuela, Cuba, Ecuador, and Peru deal on the increased number of cases intestinal parasitic infection in schoolchildren. They highlight that tropical and subtropical regions are suitable environments to the spread of parasites, as well as the degree of endemicity - which differs in the various regions of the countries -, extreme poverty, lack of basic sanitation, failure in the access to comprehensive health care, the low education of those responsible, and deficient hygiene habits are described as the main risk factors ${ }^{(6,10-14)}$.

In this context, children become protagonists since they are in a vulnerable situation due to the lack of knowledge on basic hygiene principles and because this is a formative phase of the immune system, not to mention that such pathologies directly affect the physical and cognitive development of individuals in this age, damaging the school performance. Thus, health professionals, as well as educators, exercise an important role in the process of changing hygiene habits of this population ${ }^{(1-2)}$.

Considering the data found, one can see that health education is an exit strategy for this scenario since it is focused on the teaching-learning process and has proved to be of great value to the health of the population, as it is incorporated into the personal and collective scope, making individuals aware about the risks of such diseases ${ }^{(2)}$.
The school term is essential to work with health-promoting practices (PS), actions aimed at disease prevention and strengthening of health protection factors. The school is a privileged space for the elaboration and implementation of activities because, in addition to bringing together children and adolescents at a critical stage of growth and development, it is an important communication bridge with the population ${ }^{(15)}$.

Aimed at materializing actions of health education, the School Health Program (PSE) was created, which aims at consolidating the intersectoral relationship between health and education through the connection between basic health care and elementary and secondary schools ${ }^{(16)}$. Since the nurse plays a key role in primary healthcare, they can help the integration between Primary Health Care $(\mathrm{PHC})$ and school, working together with teachers to stimulate student's responsibility on their own well-being.

Educators can use various strategies to facilitate the teachinglearning in health, and the games are an interesting possibility. Games have been employed in the pedagogic and psychopedagogic context aimed at the promotion, development, and motivation of learning, which can provided a balance between the playful and educational function ${ }^{(17)}$. In fact, the playful environment the game provides is an excellent space for the promotion of learning because, in it, the subject faces challenges, establishes hypothesis, experiences situations, solves problems, and test their limits. Also, it is described as a paradox activity, that is, at the same time that it is free and spontaneous, it is also regulated ${ }^{(18)}$.

The realization of health education works with games may be and efficient and attractive alternative for the promotion of teaching-learning on intestinal parasitic infections due to the high prevalence of these diseases in our country ${ }^{(19)}$. When the students get to know intestinal parasites through games, they become active subjects of their own learning, which may assist in the dissemination of knowledge, as well as in controlling these diseases beyond the walls of the school. Parasitic diseases covered in this study were ascariasis, amoebiasis, and giardiasis, as these are the most frequent among schoolchildren ${ }^{(19-21)}$.

\section{OBJECTIVE}

To analyze the playful educational interventions in the knowledge of schoolchildren about intestinal parasitosis.

\section{METHOD}

\section{Ethical aspects}

This study was approved by the Research Ethics Committee of the Ribeirão Preto College of Nursing (EERP) of University of São Paulo (USP). Parental consent was required for the students' participation in the study.

\section{Study design, location, and period}

This is a quasi-experimental, non-randomized study, based on pre- and post-intervention. Changes occurred in the same subjects before and after the implementation of playful activities with games were analyzed, following a intra-subject design ${ }^{(22)}$. The study was 
conducted in a public elementary school of a peripheric neighborhood in the city of Ribeirão Preto, located to the northeast of the State of São Paulo, from August/2013 to June/2015. The city of Ribeirão Preto had 604,682 inhabitants and its economy was predominantly based on agribusiness ${ }^{(23)}$. The neighborhood of the school studied is urbanized, has garbage collection, piped water, and electricity network. There is a Health Unit next to the school, offering services to the local population and the other five neighborhoods nearby.

\section{Study population}

The study population consisted in 101 students (intentional non-probabilistic), who were enrolled in the 5 th and 6 th grade.

\section{Data collection, organization and research steps}

A semi-structured questionnaire, based on a previous study performed by our research group and with minor changes to include amoebiasis and giardiasis, was applied to evaluate the students' knowledge before and after the intervention. This questionnaire was validated based on the literature, in addition to the validation by three area specialists - a parasitologist, a nurse, and an educator. In addition to specific questions about intestinal parasitosis, the questionnaire, which was individually answered by the students, also had a section to characterize the population, in which there were questions such as age, gender, and profession of the mother/ father or responsible. Playful activities with games employed active learning strategies ${ }^{(24)}$ and comprised five educational games about the biology of parasites, including evolutionary cycle, forms of contagion, diseases symptoms, and prophylaxis.

The first playful activity used a black light, aimed at demonstrating the correct technique of food and hand washing to eliminate parasites. Thus, foods (apple, lettuce etc) were "painted" with fluorescent ink and the students were asked to wash them. To evaluate if the technique had been learned by students, we light the "washed" foods with black light, revealing if there was or not any ink residue left. To complement this activity, the children played with the "Surprise Box" game, which involved passing a small box from hand to hand and, when the music stopped, the person with the box in hands would withdraw a card from within and fulfill the task described, such as: demonstrating how to properly wash hands, fruits, and vegetables.

The second activity performed was the game "For the record," consisting of a board set on the floor. Students were divided into four teams representing four players. Each player would roll a "giant" die made of eight PET bottles (polyethylene terephthalate) and coated with EVA sheets (ethylene vinyl acetate). Three sides of this die had drawings of parasites and the remaining sides had instructions such as: pass the turn, move one space, roll the dice again. The parasite revealed by the die indicated the "deck" from which one card would be drawn, which provided a question related to that parasitic disease. If the team had a correct answer to the question, they moved a space on the board.

The third activity was the "Prevention Panel," in which students were divided into five teams who would prepare a list of preventive measures against parasitic infections. This activity was aided by a crossword puzzle.
The fourth activity was the "Worms Game," in which the students were divided into three teams. Each team receive a EVA floor board with leaked letter forming the word "worm." As the teams provided a correct answer to the multiple-choice questions, they received a giant letter, also made of EVA, that should be attached to the board. The game ended wen one of the teams completed the word "Worm."

The fifth activity was the "Contagion and Prevention Measures Game," in which the students were divided into four teams and each team received a figure showing the internal organs of the human body, made of Styrofoam, and several little flags containing information, such as where the parasite enters, settles, is eliminated, among others. These flags contained false, true, and blank information. Students were asked to place the flags in the spot on the human body where that particular event happens. Finally, the teams were asked to write some measure of prevention for parasitic infections in the blank flags, which should be positioned on the side of the Styrofoam.

Each game had a running time of about 50 minutes and was performed with an interval of one week. In certain activities, aimed at assisting the establishment of knowledge, students were shown full-size human torsos made of resin, with the internal body organs exposed; parasites fixed in alcohol, and blades with parasitic eggs in the optical microscope Obj. 400x (Olympus). Teachers remained in the classroom during the activities, assisting the coordination of students; however, they did not participate in the activities, to ensure neutrality.

After completing the sequence of games, the students answered the questionnaire again (post-test), to evaluate the change of the children's knowledge regarding intestinal parasitic infections.

\section{Results analysis and statistics}

Data analysis as obtained from the students' responses to the questionnaires, which were tabulated and sorted into correct, incorrect, and incomplete. For comparison, we used the generalized version of the McNemar chi-squared test. The Null Hypothesis $(\mathrm{H} 0)$ of the test is that the marginal proportions of the table are the same. For the analysis, we used the R program version3.0.2.

\section{RESULTS}

Of the 101 schoolchildren who participated in the study, 48 (47.5\%) were female and 53 (52.5\%) were male, aged from 9 to 14 years. Most students - 45 (44.6\%) - were 11 years old. The variable "profession of the father" most mentioned by the students were the ones of basic level: truck driver, doorman, bricklayer, painter etc. Only $1(0.9 \%)$ of the fathers had higher education. As for "profession of the mother," most - 80 (79.2\%) - were also described as basic level (nanny, housekeeper, machine operator etc.) and 5 (4.9\%) had higher education (Table 1).

The adherence of the study population to hygiene habits in the pre-test phase showed that most students had the habit of washing hands after using the bathroom (93-92.08\%), whereas $71(70.30 \%)$ also had the habit of handwashing before eating. Regarding the water consumption at home, 71 (71.29\%) students responded their families consumed filtered or boiled water; 97 (96.04\%) reported that fruits and vegetables are washed with this same water and that garbage is correctly disposed of through the public service. 
Table 1 - Distribution of 5th and 6th grade students of a public elementary school according to gender, age, and parents' profession ( $N=101)$, Ribeirão Preto, São Paulo, Brazil, 2015

\begin{tabular}{|c|c|c|}
\hline \multirow{2}{*}{ Variables } & \multicolumn{2}{|c|}{ Frequency } \\
\hline & $\mathbf{n}$ & $\%$ \\
\hline \multicolumn{3}{|l|}{ Gender } \\
\hline Male & 53 & 52.5 \\
\hline Female & 48 & 47.5 \\
\hline \multicolumn{3}{|l|}{ Age } \\
\hline 9 & 1 & 1.0 \\
\hline 10 & 11 & 10.9 \\
\hline 11 & 45 & 44.6 \\
\hline 12 & 40 & 39.6 \\
\hline 13 & 3 & 3.0 \\
\hline 14 & 1 & 1.0 \\
\hline \multicolumn{3}{|l|}{ Occupation (father) } \\
\hline Inactive & 10 & 9.9 \\
\hline Basic Education & 63 & 62.4 \\
\hline Technician & 15 & 14.9 \\
\hline Higher Education & 1 & 0.9 \\
\hline Others & 12 & 11.8 \\
\hline \multicolumn{3}{|l|}{ Occupation (mother) } \\
\hline Inactive & 2 & 1.9 \\
\hline Basic Education & 80 & 79.2 \\
\hline Technician & 3 & 27.2 \\
\hline Higher Education & 5 & 4.9 \\
\hline Others & 11 & 10.8 \\
\hline
\end{tabular}

The only habits that showed a significant difference when comparing the knowledge before and after intervention were "Do you wash your hands before you eat?" $(p=0.018)$ and "Which type of water do you drink?" ( $p=0.003$ ) (Table 2 ).

Regarding the question "Which organisms are parasites?", we observed the students assigned a high number of correct responses, totaling 69 (71.29\%). As to the educational intervention, most students $(95-94.06 \%)$ understood in the post-test phase that intestinal parasites can cause human disease. The $p$ value was significant $(p<0.0001)$ (Table 3$)$.

In a positive way, it can be seen that students not only learned that intestinal parasites are causative agents of disease but also could specify the intestinal parasitic infections, and it should be noted that $65(64.36 \%)$ marked correct responses $(p<0.0001)$ at the moment of post-test application. In this scenario, we highlight the question "How can a person get worms?", which had a significant increase of correct answers in the post-test, going from $23(22.77 \%)$ in the pre-test to $86(86.86 \%)$ in the post-test. The relationship was significant, presenting a $\mathrm{p}<0,0001$ (Table 3 ). It is noteworthy that $95(94.06 \%)$ of the schoolchildren started to identify the difference between male and female worms after the educational interventions, and $85(8416 \%)$ could understand the parasite cycle.

Table 2 - Adherence to hygiene habits of 5th and 6th grade students of a public elementary school, before and after the educational activities ( $\mathrm{N}=101$ ), Ribeirão Preto, São Paulo, Brazil, 2015

\begin{tabular}{|c|c|c|c|c|c|}
\hline \multirow{2}{*}{ Hygiene habits } & \multicolumn{2}{|c|}{ Before } & \multicolumn{2}{|c|}{ After } & \multirow{2}{*}{$p$ value } \\
\hline & $\mathbf{n}$ & $\%$ & $\mathbf{n}$ & $\%$ & \\
\hline \multicolumn{6}{|l|}{ Do you wash your hands after using bathroom?* } \\
\hline No & 1 & 0.99 & 0 & 0 & 0.059 \\
\hline Yes & 93 & 92.08 & 98 & 98.02 & \\
\hline Sometimes & 7 & 6.93 & 2 & 1.98 & \\
\hline \multicolumn{6}{|l|}{ Do you wash your hands before you eat?** } \\
\hline No & 2 & 1.98 & 0 & 0 & 0.018 \\
\hline Yes & 71 & 70.30 & 81 & 80.20 & \\
\hline Sometimes & 28 & 27.72 & 18 & 19.80 & \\
\hline \multicolumn{6}{|l|}{ Which type of water do you drink? } \\
\hline Does not know & 1 & 0.99 & 2 & 1.98 & 0.003 \\
\hline Filtered or boiled & 71 & 71.29 & 88 & 87.13 & \\
\hline Sometimes & 28 & 27.72 & 11 & 10.89 & \\
\hline \multicolumn{6}{|l|}{ Do you wash fruits and vegetables before consumption? } \\
\hline Does not know & 4 & 3.96 & 5 & 4.95 & 0.655 \\
\hline Correct & 97 & 96.04 & 96 & 95.05 & \\
\hline \multicolumn{6}{|c|}{ What do you and other people in your house do with the garbage? } \\
\hline Does not know & 1 & 0.99 & 1 & 0.90 & 0.368 \\
\hline Correct & 97 & 96.04 & 98 & 97.03 & \\
\hline Incorrect & 3 & 2.97 & 2 & 1.98 & \\
\hline \multicolumn{6}{|l|}{ Have you ever done a stool exam? } \\
\hline Does not know & 18 & 18.81 & 17 & 17.82 & 0.978 \\
\hline Yes & 38 & 38.61 & 39 & 39.60 & \\
\hline No & 45 & 42.57 & 45 & 42.57 & \\
\hline
\end{tabular}

Note: Among the variables, in "Do you wash your hands after using the bathroom?"** and "Do you wash your hands before you eat?"*** one and two people were excluded, respectively, due to lack of response in the post-test.

Table 3 - Responses from 5th- to 6th-grade students of a public elementary school to specific questions about intestinal parasitosis, before and after educational activities ( $N=101)$, Ribeirão Preto, São Paulo, Brazil, 2015

\begin{tabular}{|c|c|c|c|c|c|}
\hline \multirow{2}{*}{ Question } & \multicolumn{2}{|c|}{ Before } & \multicolumn{2}{|c|}{ After } & \multirow{2}{*}{$p$ value } \\
\hline & $\mathbf{n}$ & $\%$ & $\mathbf{n}$ & $\%$ & \\
\hline \multicolumn{6}{|c|}{ Which organisms are parasites? } \\
\hline Does not know & 4 & (3.96) & & 0 & $<0.0001$ \\
\hline Correct & 7 & (7.13) & 69 & (71.29) & \\
\hline Incorrect & 85 & (84.16) & 0 & (19.80) & \\
\hline Incomplete & 4 & $(3.70)$ & 9 & $(8.91)$ & \\
\hline
\end{tabular}




\begin{tabular}{|c|c|c|c|c|c|}
\hline \multirow{2}{*}{ Question } & \multicolumn{2}{|c|}{ Before } & \multicolumn{2}{|c|}{ After } & \multirow{2}{*}{$p$ value } \\
\hline & $\mathbf{n}$ & $\%$ & $\mathbf{n}$ & $\%$ & \\
\hline \multicolumn{6}{|l|}{ Do intestinal parasites cause disease in humans? } \\
\hline Does not know & 45 & $(45.54)$ & 1 & $(0.99)$ & $<0.0001$ \\
\hline Yes & 5 & $(4.95)$ & 95 & $(94.06)$ & \\
\hline No & 50 & $(49.50)$ & 5 & $(4.95)$ & \\
\hline \multicolumn{6}{|l|}{ Which diseases are caused by parasites? } \\
\hline Does not know & 36 & $(35.64)$ & 6 & $(5.94)$ & $<0.0001$ \\
\hline Correct & 2 & $(1.98)$ & 65 & $(64.36)$ & \\
\hline Incorrect & 57 & $(56.44)$ & 19 & $(18.81)$ & \\
\hline Incomplete & 6 & $(5.94)$ & 11 & $(10.89)$ & \\
\hline \multicolumn{6}{|l|}{ What does a person who has parasites feels? } \\
\hline Does not know & 2 & $(2.02)$ & 1 & $(0.99)$ & $<0.0001$ \\
\hline Correct & 10 & $(10.01)$ & 80 & $(80.08)$ & \\
\hline Incorrect & 76 & $(76.76)$ & 9 & (9.09) & \\
\hline Incomplete & 13 & $(13.13)$ & 11 & $(11.11)$ & \\
\hline \multicolumn{6}{|l|}{ How can a person "get" worms? } \\
\hline Correct & 23 & $(22.77)$ & 86 & $(86.86)$ & $<0.0001$ \\
\hline Incorrect & 56 & $(56.56)$ & 3 & (3.96) & \\
\hline Incomplete & 20 & $(20.02)$ & 10 & $(10.01)$ & \\
\hline \multicolumn{6}{|l|}{ What distinguishes male worms from female worms? } \\
\hline Correct & 40 & $(39.60)$ & 95 & $(94.06)$ & $<0.0001$ \\
\hline Incorrect & 61 & $(60.40)$ & 6 & $(5.94)$ & \\
\hline \multicolumn{6}{|c|}{ Throughout its life cycle, does the worm settles in only one of the host's organs? } \\
\hline Does not know & 55 & $(54.46)$ & 4 & $(3.96)$ & $<0.0001$ \\
\hline No & 24 & $(23.76)$ & 85 & $(84.16)$ & \\
\hline Yes & 22 & $(21.78)$ & 12 & $(11.88)$ & \\
\hline
\end{tabular}

Note: Three people were disregarded in the variable "Which organisms are parasites?"* due to the absence of response (does not know) in the post-test.

\section{DISCUSSION}

It was shown that playful activities with games were efficient since significant changes were observed in the students' knowledge at the time of post-test. By raising this issue, authors from several Latin American countries have recognized that educational actions in health generate knowledge and empower groups and/or communities about various topics ${ }^{(9-15,20-21)}$. The increase in correct answers can be explained by some hypotheses, such as the material resources used, which instigated the interest and motivation of schoolchildren, and the playing itself, which turns the subjects into active learners ${ }^{(15-18)}$.

Given this context, authors say the pedagogical practice is responsible for contributing to the refinement of knowledge, especially if based on meaningful learning ${ }^{(25-27)}$. Thus, when planning actions, researchers must assess and use everyday situations of the population, so that the study subject will have the opportunity to relate the theme addressed to prior knowledge. On this premise, it was possible to articulate this savvy to scientific and technical knowledge assimilated during the activity, making the understanding on intestinal parasitosis more real and dynamic for schoolchildren.

One should notice that, in a study conducted in the same region here researched to identify the prevalence of intestinal parasitic infections in a population of 233 children aged from 3 to 12 years, a high prevalence of parasitoses was found (57.5\%), being Giardia lamblia the most found parasite ${ }^{(28)}$. This finding reinforces the need for implementing health education actions in this population, such as the one developed in this study.

Based on this panorama, countries such as Argentina ${ }^{(6)}$, Chile $^{(29)}$, Colombia $^{(10)}$, Cuba $^{(11)}$, Ecuador $^{(12)}$, India ${ }^{(30)}$, Indonesia ${ }^{(31)}$, Mexico ${ }^{(32)}$, Paraguay ${ }^{(33)}$, Venezuela ${ }^{(14)}$ and Uruguay ${ }^{(34)}$ have studies listing the main risk factors for contamination with parasitic diseases, highlighting housing conditions, sanitation problems, lack of drinking water, poor hygiene conditions, and climatic and environmental changes.

Defending this hypothesis, authors claim that climatic conditions may be directly related to intestinal parasitic infections. In Kalena Rongo, Indonesia(31), there is little rainfall, which leads to water and sanitation issues. The population does not wash the hands before eating and bath once a week in a public well, and this same water is used for drinking and washing foods. Thus, these factors lead to the spread of parasites, as it was identified that most children from 5-12 years of age presented polyparasitism.

It should be mentioned that the low socioeconomic level, identified by the parents' occupation, is connected with intestinal parasitic diseases. Similar situations can be seen in research conducted in Itapuranga (GO)(1), Grajaú (MA)(19), Caxias do Sul (RS) ${ }^{(20)}$, Porto Velho $(\mathrm{RO})^{(35)}$ and in Venezuela ${ }^{(36)}$, where the parents of the respondents had complete and/or incomplete elementary schooling. However, one should note that not always the low education level is related to lack of sanitary education and hygiene.

As for the gender, there was a small percentage difference when comparing males and females, showing practically equanimity. Regarding age group, most research focused on children under 14 years old, similar to this study. It is worth mentioning that a large portion of the research had as study subjects children and adolescents within the school environment ${ }^{(12,19,29,32,37)}$.

Given this context, the gap in knowledge and the high prevalence of intestinal parasites in the population studies points to the need for paying more attention to the objectives proposed by the Ministry of Health, through the integrated Plan of strategic actions for the elimination of leprosy, filariasis, schistosomiasis and onchocerciasis as a public health problem, trachoma as a cause of blindness and control of geohelminthiasis ${ }^{(8)}$, both in the municipal context and in State and Federal spheres. These 
Playful educational intervention with schoolchildren on intestinal parasitosis Bragagnollo GR, Santos TS, Fonseca REP, Acrani M, Castelo Branco MZP, Ferreira BR.

objects include standardizing, coordinating, and evaluating strategic actions of prevention and control; identifying their main risk factors, and developing continuing education actions. It is not enough to just offer minimal sanitation conditions and public policies for urban planning and housing, there is also a need for encouraging educational practices for the prevention of parasitic diseases to empower the population ${ }^{(15)}$.

The playful activities offered helped the students to efficiently identify the form of transmission of parasites, which is fundamental to establish actions for preventing intestinal parasitoses. Studies show that learning about prophylactic habits decreases the prevalence of infections and, consequently, the spending on medical care ${ }^{(17-19,36-38)}$.

Considering the facts mentioned, one can observe that, after the playful activities with games, the students had a higher number of correct answers on the topic in all the questions. These findings show, after the implementation of playful activities, the increased knowledge of students regarding hygiene habits described by them - most students responded they washed their hands after using the bathroom and before eating, essential and very efficient habits to prevent intestinal parasitic infections. In this context, a study developed in Bahia pointed out that "actions on the prevention process of parasitic diseases should be continuously implemented in the school environment, so that in the future more critical and healthy citizens may be formed"(37). When viewing a study developed and implemented in public schools in Mexico, one can similarly observed that the knowledge of schoolchildren exposed to educational modules improved after the intervention $^{(32)}$.

Results presented here show that playful activities may provide a significant learning, actively contributing to health promotion. In addition to learning about parasitic infections, the set of games made possible for students to know better their own bodies, thus being able to take care of themselves and adopt healthy habits, as emphasized by the National Curriculum Parameters (PCN) of elementary school(17-19,37).

Also relevant is to deal with the importance of socio-educational campaigns to disseminate information and encourage the participation and cooperation of parents and society, aiming at reducing the spread of parasitic diseases. Such results show that behavioral changes in the community are necessary for achieving detectable improvements regarding the prevalence of parasitic diseases and/or the transmission of other parasitic infections ${ }^{(38)}$.

\section{Study limitations}

As limitations of this study, we highlight the short period of time for implementation of the playful intervention, the lack of monitoring of the impact of this activities on long-term behavior changes and knowledge of students, and the restriction of the study to a single school in Ribeirão Preto. However, the results obtained are an initial step to show that playful educational interventions on intestinal parasitic infections can be used as a didactical resource for improving the teaching-learning process of schoolchildren.

\section{Contributions to the fields of nursing, health or public policy}

Given this context, the study contributed by presenting a new didactic material for the teaching-learning process on intestinal parasitoses. This will enable the development and production of new tools for the education of schoolchildren, thus strengthening teacher-student relationships, as well as the integration and interaction of health professionals in the school environment, and allowing for interdisciplinary participation, which shall serve to the development and implementation of public policies on many health-related topics.

\section{CONCLUSION}

Analysis of results allowed concluding that playful educational interventions are extremely important in the teaching-learning process of schoolchildren. The playful activities with games implemented in the school were efficient for improving the students' hygiene habits. The use of games in the teaching-learning process has proved to be an excellent educational resource and a great strategy for extension actions in health education programs. Thus, it is expected that games about intestinal parasitic infections contribute not only to the appropriation of knowledge but also to sensitize teachers and educators on the richness of this kind of resource, encouraging the development of new didactic games about other themes since such actions, in addition to including playful aspects, favor the reasoning, motivation, and the students-student and student-educator interactions.

\section{FUNDING}

This project received funding from the São Paulo Research Foundation (FAPESP).

\section{REFERENCES}

1. Silva AO, Cunha CRM, Martins WLL, Silva LS, Silva GRC, Fernandes CKC. Epidemiologia e prevenção de parasitoses intestinais em crianças das creches municipais de Itapuranga - GO. Rev Facul Montes Belos[Internet]. 2015 [cited 2016 Jun 02];8(1):1-17. Available from: http://revista. fmb.edu.br/index.php/fmb/article/viewFile/18/14

2. Maia CVA, Hassum IC. Parasitoses intestinais e aspectos sociossanitários no Nordeste brasileiro no século XXI: uma revisão de literatura. Hygeia [Internet]. 2016 [cited 2017 Apr 7];12(23):20-30. Available from: http://www.seer.ufu.br/index.php/hygeia/article/ viewFile/34865/19481

3. Instituto Trata Brasil. Base de dados de 2015, SNIS - Sistema Nacional de Informações de Saneamento. Ranking do saneamento das 100 maiores cidades - 2017. [Internet]. 2016 [cited 2016 Jun 4]. Available from: http://www.tratabrasil.org.br/datafiles/estudos/ranking/2017/ tabela-100-cidades.pdf 
Playful educational intervention with schoolchildren on intestinal parasitosis Bragagnollo GR, Santos TS, Fonseca REP, Acrani M, Castelo Branco MZP, Ferreira BR.

4. World Health Organization. Eliminating soil-transmitted helminthiases as a public health problem in children. Progress Report 2001-2010 and Strategic Plan 2011-2020. Geneva: WHO; 2012. [cited 2016 Jun 2]. Available from: http://apps.who.int/iris/ bitstream/10665/44804/1/9789241503129_eng.pdf

5. Ministério da Saúde (BR). Secretaria de Vigilância em Saúde. Coordenação-Geral de Desenvolvimento da Epidemiologia em Serviços. Guia de Vigilância em Saúde [Internet]. 2017 [cited 2017 Jul 10]. Available from: http://www.rio.rj.gov.br/dlstatic/10112/6385405/4170293/ GUIADEVS2016.pdf

6. Navone GT, Zonta ML, Cociancic P, Garraza M, Gamboa MI, Giambelluca LA, et al. Estudio transversal de las parasitosis intestinales en poblaciones infantiles de Argentina. Rev Panam Salud Publica [Internet]. 2017 [cited 2017 Jul 8]. Available from: http://iris.paho.org/xmlui/ bitstream/handle/123456789/33879/v41a24.pdf?sequence=1\&isAllowed=y

7. Nicholls S. Parasitismo intestinal y su relación con el saneamiento ambiental y las condiciones sociales en Latinoamérica y el Caribe. Biomédica [Internet]. 2016 [cited 2017 Jul 10];36(4):496-7. Available from: https://www.revistabiomedica.org/index.php/biomedica/article/ view/3698

8. Ministério da Saúde (BR). Secretaria de Vigilância em Saúde. Departamento de vigilância em Doenças Transmissíveis. Plano integrado de ações estratégicas de eliminação da hanseníase, filariose, esquistossomose e oncocercose como problema de saúde pública, tracoma como causa de cegueira e controle das geohelmintíases: Plano de ação 2011-2015 [Internet]. Brasília, DF; 2012 [cited 2017 Jun 12]. Available from: http://bvsms.saude.gov.br/bvs/publicacoes/plano_integrado_acoes_estrategicas_2011_2015.pdf

9. Silva JA, Silva AS, Capristo AP, Cardoso CG, Karen C, Ferreira DP, et al. Prevalência de enteroparasitoses em alunos da Escola Municipal Jardim Marília, localizada na Zona Leste do município de São Paulo. Sci Health [Internet]. 2015 [cited 2017 Jul 8];6(3):157-63. Available from: http:// arquivos.cruzeirodosuleducacional.edu.br/principal/new/revista_scienceinhealth/18_set_dez_2015/Science_03_2015_157-63.pdf

10. Lucero-Garzón T, Alvarez-Motta LA, Chicue-Lopez JF, Lopez-Zapata D, Mendoza-Bergaño CA. Parasitosis intestinal y factores de riesgo en niños de los asentamientos subnormales, Florencia-Caquetá, Colombia. Rev Fac Nac Salud Pública [Internet]. 2015[cited 2017 Jun 7];33(2):171-80. Available from: http://revmedtropical.sld.cu/index.php/medtropical/article/view/93/94

11. Cazorla-Pastor J, Perez-Morales M, Mas S, Marin B. Comportamiento de parasitismo intestinal en el área de salud de Potrerillo. Medisur [Internet]. 2016 [cited 2017 Jul 11];13(6):763-69. Available from: http://medisur.sld.cu/index.php/medisur/article/view/3103

12. Ordoñez TEP. Prevalencia de Cryptosporidium spp y Giardia spp en terneros, y su presencia en agua y en niños con problemas digestivos en el cantón San Fernando, Ecuador. Rev Maskana [Internet]. 2017. [cited 2017 Jul 11];8(1),111-9. Available from: https://publicaciones. ucuenca.edu.ec/ojs/index.php/maskana/article/view/1193/pdf_1

13. Pinto M, Quispe L, Ramos L, Quispe J, Ramos A, Principe J, et al. Prevalencia de enteroparasitismo y su relación con la pobreza y el hacinamiento en niños de Huarangal, 2014. CIMEL. [Internet]. 2016 [cited 2016 Jun 2];21(2)14-8. Available from: http://www.cimel.felsocem. net/index.php/CIMEL/article/view/646/364

14. Mata M, Parra A, Sanchez K, Alviarez Y, Perez-Ybarra L, Relación clínico-epidemiológica de Giardiasis en niños de 0-12 años que asisten a núcleos de atención primaria. Municipio Francisco Linares Alcántara, estado Aragua, Venezuela. Comunidad Salud [Internet]. 2016 [cited 2017 Jul 3];14(1):1-9. Available from: http://www.redalyc.org/articulo.oa?id=375746275002

15. Costa GMC, Cavalcanti VM, Barbosa ML, Celino SDM, França ISX, Sousa FS. Promoção de saúde nas escolas na perspectiva de professores do ensino fundamental. Rev Eletr Enf [Internet]. 2013 [cited 2017 Jun 22];15(2):506-15. Available from: https://www.fen.ufg.br/fen_revista/v15/ n2/pdf/v15n2a25.pdf

16. Ministério da Educacao (BR). Ministério da Saude (BR). Portaria Interministerial n 1.055, de 25 de abril de 2017[Internet]. Brasília, DF; 2017 [cited 2017 Jul 07]. Available from: http://www.brasilsus.com.br/images/portarias/abril2017/dia26/portint1055.pdf

17. Arruda SG, Silva RAS. A importância do lúdico na educação infantil e demais fases na visão da psicopedagogia. Rev Miríade Científica [Internet]. 2017 [cited 2017 Jun 24];1(2):1-21. Available from: http://www.psicologia.pt/artigos/textos/A0358.pdf

18. Alves L, Bianchin MA. O jogo como recurso de aprendizagem. Rev Psicopedag [Internet]. 2010 [cited 2016 Jun 5];27:282-7. Available from: http://www.revistapsicopedagogia.com.br/detalhes/210/o-jogo-como-recurso-de-aprendizagem

19. Gomes SCS, Rodrigues SR, Silva AB, Arruda AKS, Silva NM, Macedo RS, et al. Educação em saúde como instrumento de prevenção das parasitoses intestinais no município de Grajaú - MA. Pesq em Foco. [Internet]. 2016 [cited 2017 Jul 16];21(1):34-45. Available from: http:// ppg.revistas.uema.br/index.php/PESQUISA_EM_FOCO/article/view/1123

20. Camello JT, Cavagnolli NI, Spada PKWDS, Poeta J, Rodrigues AD. Prevalência de parasitoses intestinais e condições de saneamento básico das moradias em escolares da zona urbana de Caxias do Sul, Rio Grande do Sul. Sci Med[Internet]. 2016 [cited 2017 Jul 15];26(1):1-6. Available from: http://revistaseletronicas.pucrs.br/ojs/index.php/scientiamedica/article/view/21716

21. Oliveira ESL, Silva JS. Índice de parasitoses intestinais nas zonas urbana e rural do município de Caputira - estado de Minas Gerais. Rev Pens Acad [Internet]. 2016 [cited 2017 Jun 26];14(2):143-52. Available from: http://www.pensaracademico.facig.edu.br/index.php/ pensaracademico/article/view/11

22. Alberto PA, Troutman AC. Single-subject designs: applied behavior analysis for teachers. Columbus: Merrill Prentice Hall; 2003. 15:167-227

23. Instituto Brasileiro de Geografia e Estatística. São Paulo - Ribeirão Preto[Internet]. 2017[cited 2017 Jul 07]; Available from: https://www.ibge. gov.br/

24. Moran JMA. Educação que desejamos: novos desafios e como chegar lá. Rev Educ PUC Campinas [Internet]. 2007 [cited 2017 Jul 7];24:12131. Available from: http://periodicos.puc-campinas.edu.br/seer/index.php/reveducacao/article/viewFile/121/108 
Playful educational intervention with schoolchildren on intestinal parasitosis Bragagnollo GR, Santos TS, Fonseca REP, Acrani M, Castelo Branco MZP, Ferreira BR.

25. Prefeitura Municipal de Ribeirão Preto (SP). Referencial Curricular. Ensino fundamental: anos finais. Ribeirão Preto; 2012.

26. Krasilchik M. Prática de ensino de biologia. $4^{a}$ ed. São Paulo (SP): Edusp; 2005.

27. Ausubel DP, Novak JD, Hanesian H. Psicologia educacional. Rio de Janeiro (RJ): Interamericana; 1980.

28. Fonseca REP, Barbosa MCR, Ferreira BR. High prevalence of enteroparasites in children from Ribeirão Preto, São Paulo, Brazil. Rev Bras Enferm [Internet]. 2017 [cited 2017 Jul 16];70(3):566-71. Available from: http://www.scielo.br/pdf/reben/v70n3/0034-7167-reben-70-03-0566.pdf

29. Barra M, Bustos L, Ossa X. Desigualdad en la prevalencia de parasitosis intestinal en escolares de una escuela urbana y dos rurales de la comuna de Puerto Montt. Rev Méd Chile [Internet]. 2016 [cited 20170 Jul 7];144(7):886-93. Available from: https://scielo.conicyt.cl/pdf/rmc/ v144n7/art09.pdf

30. Sunish IP, Rajendran R, Munirathinam A, Kalimuthu M, Ashok Kumar V, Nagaraj J, et al. Impact on prevalence of intestinal helminth infection in school children administered with seven annual rounds of diethyl carbamazine (DEC) with albendazole. Indian J Med Res [Internet]. 2015 [cited 2017 Jun 22];141(3):3309. Available from: https://www.ncbi.nlm.nih.gov/pubmed/25963494

31. Sungkar S, Pohan APN, Ramadani A, Albar N, Azizah F, Nugraha ARA, et al. Heavy burden of intestinal parasite infections in Kalena Rongo village, a rural area in South West Sumba, eastern part of Indonesia: a cross sectional study. Indian J Med Res [Internet]. 2015 [cited 2017 Jul 14];141(3):330-9. Available from: https://www.ncbi.nlm.nih.gov/pmc/articles/PMC4690433/?tool=pubmed

32. Perez RR, Valdez EA, Rodriguez MJC, Cota LQ, Figueroa GGM. Aplicación de un modelo educativo para prevenir parasitosis intestinal. Estud Soc[Internet]. 2014 [cited 2017 Jul 14];22(44):92-117. Available from: http://www.scielo.org.mx/pdf/estsoc/v22n44/v22n44a4.pdf

33. Exangue G, Sosa L, Diaz V, Ruiz I, Rivas L, Granado D, et al. Enteroparasitosis en niños bajo 5 años de edad, indígenas y no indígenas, de comunidades rurales del Paraguay. Rev Chil Infectol [Internet]. 2015 [cited 2017 Jul 11];32(6):649-57. Available from: https://scielo.conicyt.cl/ $\mathrm{pdf} / \mathrm{rci} / \mathrm{v32n6/art06.pdf}$

34. Melgar ME, Mendaro A, Pizzorno N, Poloni A, Rebora MF, Delfino M. Prevalencia de parasitosis intestinal en niños. An Facultad Med (Univ Repúb Urug) [Internet]. 2016. [cited 2017 Jul 10];3(1):23-29. Available from: http://www.anfamed.edu.uy/index.php/rev/article/view/180

35. Rodrigues PCO, Ignotti E, Hacon SS. Características socioeconômicas, demográficas e de saúde de escolares residentes em duas comunidades da Amazônia meridional brasileira. Rev Ciên Est. Acad Med [Internet]. 2016 [cited 2017 Jun 2];(6):10-23. Available from: http:// periodicos.unemat.br/index.php/revistamedicina/article/view/1490

36. Guevara YCL, Rodicio EH, Guevara YCL, Garcia VN, Gamboa MG. Parasitismo intestinal en niños de 0-14 años. Intervención educativa a los padres. Rev Inf Cient [Internet]. 2015 [cited 2017 Jul 6]; 93(5):1143-53. Available from: http://www.revinfcientifica.sld.cu/index.php/ric/ article/view/184/1188

37. Pereira C, Silva MC. Fatores de risco das enteroparasitoses de escolares públicos da Bahia. Rev Saúde Com [Internet]. 2014 [cited 2017 Jul 11];10(3):245-253. Available from: http://www.uesb.br/revista/rsc/ojs/index.php/rsc/article/view/231

38. Souza AC, Alves FV, Guimarães HR, Amorim ACS, Cruz MA, Santos BS, Borges EP, et al. Perfil epidemiológico das parasitoses intestinais e avaliação dos fatores de risco em indivíduos residentes em um assentamento rural do nordeste brasileiro. Rev Conexão UEPG [Internet]. 2016 [cited 2017 Jul 9];12(1):27-35. Available from: http://www.revistas2.uepg.br/index.php/conexao/article/view/7807/5171 